Article

\title{
In Vitro Antifungal Activity of Plant Extracts on Pathogenic Fungi of Blueberry (Vaccinium sp.)
}

\author{
Abraham Hernández-Ceja ${ }^{1}$, Pedro Damián Loeza-Lara ${ }^{2} \mathbb{D}$, Francisco Javier Espinosa-García ${ }^{3}$ (D), \\ Yolanda M. García-Rodríguez ${ }^{3}{ }^{\mathbb{D}}$, José Roberto Medina-Medrano ${ }^{4}\left(\mathbb{D}\right.$, Germán Fernando Gutiérrez-Hernández ${ }^{5}(\mathbb{D}$ \\ and Luis Fernando Ceja-Torres $1, * \mathbb{D}$
}

1 Instituto Politécnico Nacional, Centro Interdisciplinario de Investigación para el Desarrollo Integral Regional Unidad Michoacán, Jiquilpan, MI 59510, Mexico; Abm_hernandez@hotmail.com

2 Licenciatura en Genómica Alimentaria, Universidad de La Ciénega del Estado de Michoacán de Ocampo, Sahuayo, MI 59103, Mexico; pdloeza@ucienegam.edu.mx

3 Instituto de Investigaciones en Ecosistemas y Sustentabilidad, Universidad Nacional Autónoma de México, Morelia, MI 58190, Mexico; espinosa@cieco.unam.mx (F.J.E.-G.); ygarcia@cieco.unam.mx (Y.M.G.-R.)

4 CONACYT-Centro Interdisciplinario de Investigación Para el Desarrollo Integral Regional Unidad Michoacán, Instituto Politécnico Nacional, Jiquilpan, MI 59510, Mexico; jrmedina@conacyt.mx

5 Instituto Politécnico Nacional, Unidad Profesional Interdisciplinaria de Biotecnología, Ticomán, CDMX 07340, Mexico; gfgutierrez@ipn.mx

* Correspondence: lfceja@ipn.mx; Tel.: +52-(353)-533-0218 (ext. 82945)

Citation: Hernández-Ceja, A.; Loeza-Lara, P.D.; Espinosa-García, F.J.; García-Rodríguez, Y.M.;

Medina-Medrano, J.R.;

Gutiérrez-Hernández, G.F.;

Ceja-Torres, L.F. In Vitro Antifungal Activity of Plant Extracts on Pathogenic Fungi of Blueberry (Vaccinium sp.). Plants 2021, 10, 852. https://doi.org/10.3390/plants10050852

Academic Editor: Laura

Grațiela Vicaș

Received: 23 March 2021

Accepted: 21 April 2021

Published: 23 April 2021

Publisher's Note: MDPI stays neutral with regard to jurisdictional claims in published maps and institutional affiliations.

Copyright: (c) 2021 by the authors. Licensee MDPI, Basel, Switzerland. This article is an open access article distributed under the terms and conditions of the Creative Commons Attribution (CC BY) license (https:// creativecommons.org/licenses/by/ $4.0 /)$.

\begin{abstract}
Three pathogenic fungi of blueberry (Vaccinium spp.) responsible for dieback disease, identified as Pestalotiopsis clavispora, Colletotrichum gloeosporioides and Lasiodiplodia pseudotheobromae, were isolated in the northwestern region of the state of Michoacán, Mexico. The mycelial growth in vitro of these fungi was inhibited by extracts from Lantana hirta, Argemone ochroleuca and Adenophyllum porophyllum, medicinal plants collected in Sahuayo, Michoacán, Mexico. The extracts showed different degrees of inhibition; the most effective were: M5L extract from L. hirta and M6LFr extract from A. ochroleuca, both of which inhibited $100 \%$ of the mycelial growth of P. clavispora and C. gloeosporioides; and M4LS extract from A. porophyllum, which inhibited $100 \%$ of the mycelial growth of the three pathogens. The extracts were fractionated by thin layer and column chromatography, and the most active fractions were analyzed by gas chromatography-mass spectrometry. The major compounds identified in L. hirta extract were Phytol and $\alpha$-Sitosterol. The compounds identified in A. ochroleuca were Toluene and Benzene, 1,3-bis(3-phenoxyphenoxy)-. In A. porophyllum, the compound identified was Hexanedioic acid, bis(2-ethylhexyl) ester. These results show the potential of L. hirta, A. ochroleuca and A. porophyllum as a source of antifungal compounds.
\end{abstract}

Keywords: thin layer chromatography; column chromatography; antifungal extracts; gas chromatography-mass spectrometry; antifungal compounds

\section{Introduction}

The main producers of blueberry are the United States, Canada and Poland; Mexico is ranked 18th. In this country, the major producing states are Michoacán and Jalisco, with 37,090 t produced in 2019 [1]. In the northwestern region of the state of Michoacán, Mexico, the production of blueberry is affected by various factors; among the most important are diseases caused by Pestalotiopsis sp.; Colletotrichum sp.; and other fungi belonging to the family Botryosphaeriaceae, such as Lasiodiplodia theobromae, Neofusicoccum ribis and Botryosphaeria sp. [2-4]. These fungi have the ability to affect fruits and stems, causing the disease known as dieback $[5,6]$, which is responsible for significant losses in the production of blueberries and the increase in production costs related to fungicides. The continuous and indiscriminate use of fungicides causes adverse effects to human health and the environment [7], which, together with the increasing demand for blueberries, current regulations on chemical pesticides and the emergence of resistant pathogens, justifies the search for new active 
molecules that can be used as control agents against phytopathogenic fungi $[7,8]$ and that can be included in programs associated with the integrated management of pests.

Secondary metabolites with fungicidal properties have biological activity against phytopathogenic fungi and are, therefore, a viable control option. They are biodegradable to non-toxic products and could be a sustainable tool as bio-pesticides in integrated pest management programs [9-11]. The main source of these metabolites can be found in medicinal plants, of which more than 200 species with this activity have been studied and reported in Mexico [12]. The state of Michoacán, Mexico, has an enormous wealth of plant species and important cultural traditions on the use of medicinal plants, such as "Siete Colores", "Chicalote" and "Árnica de Cerro", which are widely used as analgesics, and antidiarrheal, anti-inflammatory and antimicrobial remedies [13-15]. To our knowledge, no studies have been conducted to identify the bioactive secondary metabolites of these species or to evaluate their antifungal activity against the major pathogenic fungi of blueberries grown in the northwestern region of the state of Michoacán, Mexico.

Thus, the objectives of this study were to identify the main fungi responsible for causing dieback disease in blueberries; to evaluate the in vitro antifungal activity of extracts from Lantana hirta, Argemone ochroleuca and Adenophyllum porophyllum against fungi associated with this disease; and to identify the bioactive secondary metabolites present in these plant species.

\section{Material and Methods}

\subsection{Isolation of Pathogenic Fungi of Blueberry}

Diseased plants with symptoms of wilt, blight, canker and dieback were collected from plots in the following four municipalities that produce blueberries in the northwest of the state of Michoacán, Mexico: Emiliano Zapata, Los Palillos, La Magdalena and San Gregorio. The fungi were isolated according to the procedure previously published [16]. For this, fragments of diseased tissue of approximately $10 \times 10 \mathrm{~mm}$ were obtained from the diseased plants collected; disinfested with 3\% (v/v) sodium hypochlorite for $2 \mathrm{~min}$, rinsed three times with sterile distilled water; and dried on sterile paper napkins for $20 \mathrm{~min}$, in a laminar flow cabinet (CHC Biolus ${ }^{\circledR}$, Daejeon, Korea). Five fragments of sick tissue were transferred per Petri dishes containing potato-dextrose-agar culture medium (PDA, Bioxon ${ }^{\circledR}$, Estado de México, Mexico) and incubated at $28^{\circ} \mathrm{C}$ for $4-7$ days, until fungal growth. The fungal isolates were purified using the hyphal tip technique, as follows: the colonies were transferred to water-agar culture medium $(20 \%)\left(\right.$ Bioxon $\left.^{\circledR}\right)$, where they were left to grow for 3 days at $28^{\circ} \mathrm{C}$; hyphal tips were then removed and transferred individually to PDA medium. The fungi grown on PDA were kept on sterile filter paper $\left(2 \mathrm{~cm}^{2}\right)$ for 15 days. Finally, they were placed in a sterile container and left in refrigeration at $5{ }^{\circ} \mathrm{C}$ until further use.

\subsection{Molecular Identification of Fungi}

The molecular identification of the fungi was carried out by polymerase chain reaction (PCR) using oligonucleotides specific for the ITS regions of rDNA. The extraction and quantification of DNA was performed according to the method of Raeder and Broda [17]. The fungal DNA was purified using The Wizard ${ }^{\circledR}$ Genomic DNA Purification Kit (A1120, Promega Corp., Madison, WI, USA). The PCR was performed using the primers ITS1-Fwd (5'-TCCGTAGGTGAACCTGCGG-3') and ITS4-REV (5'-TCCTCCGCTTATTATTGATATGC$\left.3^{\prime}\right)$. PCR reactions were performed in a final volume of $25 \mu \mathrm{L}$ using the GoTaq ${ }^{\circledR}$ Green Master Mix kit (M7122, Promega Corp. Madison, WI, USA) $1 \mathrm{X} ; 5 \mu \mathrm{M}$ of the primer ITS1-Fwd primer; $5 \mu \mathrm{M}$ of ITS4-Rev; and $25 \mathrm{ng}$ of genomic DNA. Amplification was performed in a $\mathrm{C} 1000$ thermal cycler (Bio-Rad ${ }^{\circledR}$, Germany) under the following conditions: initial denaturation at $94{ }^{\circ} \mathrm{C}$ for $5 \mathrm{~min}$, followed by 35 cycles of denaturation at $95{ }^{\circ} \mathrm{C}$ for $30 \mathrm{~s}, 58{ }^{\circ} \mathrm{C}$ for $30 \mathrm{~s}, 72{ }^{\circ} \mathrm{C}$ for $1 \mathrm{~min}$ and a final extension at $72{ }^{\circ} \mathrm{C}$ for $7 \mathrm{~min}$. The PCR products were separated by agarose gel electrophoresis (2\%) at $80 \mathrm{~V}$ for $40 \mathrm{~min}$, and visualized using SYBR Gold ${ }^{\circledR}$ (Invitrogen, Carlsbad, CA, USA). DNA fragments of 
700 bp were selected for purification with ExoSAP-IT ${ }^{\circledR}$ (N/P 78200, USB Affymetrix, Inc., Cleveland, $\mathrm{OH}, \mathrm{USA})$. The purified fragments were sequenced using primer ITS1-Forward (5'-TCCGTAGGTGAACCTGCGG-3') and ITS4-Rev (5'-TCCTCCGCTTATTATTGATATGC$3^{\prime}$ ) with the ABI PRISM BigDye ${ }^{\circledR}$ Terminator sequencing kit v3.1 (P/N 4336917, Applied Biosystems, Foster City, CA, USA). Fragment analysis was conducted in a Genetic Analyzer 3130 sequencer (Applied Biosystems ${ }^{\circledR}$, HITACHI Tokyo, Japan). The sequences were assembled using SeqMan software 8 (LaserGene) (DNASTAR ${ }^{\circledR}$, Madison, WI, USA) and analyzed using the GenBank database (www.ncbi.nlm.gov accessed on 8 May 2014).

\subsection{Pathogenicity Tests}

Pathogenicity tests were performed on months-old blueberry plants (cv. Biloxi) obtained from Centro Regional Universitario Centro Occidente (CRUCO) of Chapingo Autonomous University, Campus Morelia, Michoacán. Each plant was transplanted into plastic pots $(8 \mathrm{~L})$ with a soil $(80 \%)$ and chicken manure vermicompost-based substrate $(20 \%)$. Pure four days-old fungal cultures were used for inoculation. The experimental design consisted of randomized blocks with four treatments (three fungi and a single control with PDA only) and five repetitions. Three stems of each plant (experimental unit) were inoculated through a $1 \mathrm{~cm}$ incision on which a disc (5 $\mathrm{mm}$ in diameter) with PDA and mycelium of the corresponding strain was placed; parafilm was used to keep the disc firmly on the stem. The plants were inspected daily until the onset of symptoms.

\subsection{Collection and Identification of Plants}

The collection of Siete Colores, Chicalote and Árnica de Cerro was done during the flowering stage (July and August 2013) in Sahuayo, Michoacán, Mexico, located northwest of the state $\left(20^{\circ} 03^{\prime} \mathrm{N}\right.$ and $102^{\circ} 44^{\prime} \mathrm{W}$ and 1530 masl). The collected plants were identified by MSc Ignacio Garcia Ruiz as Lantana hirta (001-2013), Argemone ochroleuca (002-2013) and Adenophyllum porophyllum (003-2013); they are registered in the herbarium CIMI of CIIDIR-IPN Unidad Michoacán.

\subsection{Obtaining Crude Extracts and Fractions}

The plants were sectioned into roots, stems, leaves, flowers and fruits, which were disinfected with $1 \%$ sodium hypochlorite, rinsed with distilled water and dried with absorbent paper [18]. The crude extracts were obtained from the following plant organs: leaf (L) and flower (Fl) of L. hirta; leaf-fruit (LFr) and root (R) of A. ochroleuca; and leaf-stem (LS) and leaf of $A$. porophyllum. These organs were dehydrated in an oven (CRAFT ${ }^{\circledR}$, Ciudad de México, Mexico) at $50{ }^{\circ} \mathrm{C}$ for three days; they were then left at room temperature $\left(25^{\circ} \mathrm{C} \pm 2.0\right)$ for five days [19] and ground using a conventional blender. The extracts were obtained by maceration [20]; $15 \mathrm{~g}$ of the dry and ground material were mixed with $100 \mathrm{~mL}$ of absolute ethanol (EtOH, J.T. Baker ${ }^{\circledR}$ ) or $100 \mathrm{~mL}$ of ethyl acetate (AcOEt, J.T. Baker $^{\circledR}$ ) to obtain each extract. Each mixture was placed in separate $200 \mathrm{~mL}$ beakers, which were kept in the dark and left to stand for $120 \mathrm{~h}$ at room temperature $\left(25^{\circ} \mathrm{C} \pm 2.0\right)$. After this time, the extracts were filtered (Whatman ${ }^{\circledR}$ filter paper no. 5) and dried at $50{ }^{\circ} \mathrm{C}$ in a rotary evaporator (Brinkmann/Büchi $\left.{ }^{\circledR}\right)$. They were then weighed and all the extracts were re-dissolved in EtOH, adjusted to a concentration of $100 \mathrm{mg} / \mathrm{mL}$ and stored at $4{ }^{\circ} \mathrm{C}$ until further use.

The crude extracts with the highest antifungal activity were fractionated by thin layer chromatography (TLC) and column chromatography (CC). Thin layer chromatography was carried out using a mixture of hexane/ethyl acetate/methanol 80:20:1 v/v (J.T. Baker $\left.^{\circledR}\right)$, on aluminum plates precoated with silica gel $60 \mathrm{~F} 254\left(3.5 \mathrm{~cm} \times 9 \mathrm{~cm}\right.$; Whatman $\left.{ }^{\circledR}\right)$. After chromatography, the plates were left to dry outdoors and exposed to UV light (SPECTROLINE ${ }^{\circledR}$, Spectronics Corporation, Westbury, New York, NY, USA). Finally, the plates were revealed with $10 \%$ sulfuric acid (Fermont ${ }^{\circledR}$, Monterrey, NL, Mexico) to observe the bands [21]. 
Column chromatography was carried out using a glass column (50 $\mathrm{cm}$ in length) packed with $120 \mathrm{~g}$ of silica gel (Sigma ${ }^{\circledR}$, St. Louis, MO, USA). The extract was eluted with a mixture of hexane-ethyl acetate-methanol 80:20:1 $(v / v)$. The collected fractions were analyzed by TLC to verify their successful separation and each fraction was concentrated with nitrogen $\left(\mathrm{N}_{2}\right)$ to $1 \mathrm{~mL}$ and stored at $5{ }^{\circ} \mathrm{C}$.

\subsection{Antifungal Activity Assays}

A total of 12 extracts were obtained. Each extract was assayed with 0.5, 1, 2 and $5 \mathrm{mg} / \mathrm{mL}$. The effect of the crude extracts on the mycelial growth of the fungi isolated from blueberry was evaluated according to the method proposed by Sánchez-Pérez et al. [22]. Each concentration was added to Petri dishes with PDA culture medium; $30 \mathrm{~min}$ after to allow the evaporation of $\mathrm{EtOH}$ and the diffusion of the extract, a disc of $5 \mathrm{~mm}$ in diameter with PDA and mycelium of the corresponding strain was placed in the center of the dish, which was then incubated at $28^{\circ} \mathrm{C}$. In addition, we included an absolute control (PDA + fungus), a negative control (PDA + fungus $+\mathrm{EtOH}$ ) and a positive control (PDA + fungus + Thiabendazole $5 \mathrm{mg} / \mathrm{mL}$, TECTO $60^{\circledR}$ wettable powder, $600 \mathrm{~g} \mathrm{IA} \mathrm{kg}^{-1}$ ). All bioassays were performed in triplicate. The effect of extracts and fractions was determined by measuring the diameter of the colonies with a digital vernier (Fisher Scientific, Waltham, MA, USA), and expressed as the percentage inhibition of mycelial growth compared to the negative control, according to the formula: \% inhibition = average mycelial growth of the control-average mycelial growth of the treatment/average mycelial growth of the control $\times 100$ [23].

\subsection{Identification of Bioactive Secondary Metabolites}

The fractions with the strongest antifungal effect were analyzed by gas chromatographymass spectrometry (GC-MS) using the fragrance method [24]. From each sample, $1 \mu \mathrm{L}$ was analyzed with an Agilent 6890 (Agilent Technologies, Santa Clara, CA, USA) Gas Chromatography equipment with an HP-5MS (5\% Phenyl 95\% dimethylpolysiloxane) capillary column ( $30 \mathrm{~m} \times 0.25 \mathrm{~mm}$ with $0.25 \mu \mathrm{m}$ film thickness), which was coupled to an Agilent $5973 \mathrm{~N}$ selective mass detector. Helium was used as a carrier gas at 7.67 psi with a $1.0 \mathrm{~mL} \mathrm{~min}{ }^{-1}$ constant flow. The front inlet was maintained at $280^{\circ} \mathrm{C}$ in a split ratio of 50:1. The initial oven temperature was set at $50{ }^{\circ} \mathrm{C}$, which was increased to $280{ }^{\circ} \mathrm{C}$ at a rate of $5^{\circ} \mathrm{C} \mathrm{min}^{-1}$ and then held for $1 \mathrm{~min}$ at this constant temperature, subsequently increased to $380^{\circ} \mathrm{C}$ at a rate of $25^{\circ} \mathrm{C} \mathrm{min}-1$ and finally held at the temperature of $380^{\circ} \mathrm{C}$ for $3 \mathrm{~min}$. The mass spectrometer was operated in electrical ionization mode (EI), with a flow of $1 \mathrm{~mL} \min ^{-1}, 70 \mathrm{eV}$ ionization voltage, the interface temperature at $300^{\circ} \mathrm{C}$ and a scan range of $50-500 \mathrm{~m} / \mathrm{z}$. The compounds were identified by comparing the mass spectra of each constituent with those stored in the NIST02.L database. We only accepted peaks with a degree of purity of one, and the spectra were identified using a concordance threshold of $90 \%$. The relative abundance of each compound was estimated by dividing its peak area by the sum of the areas of all peaks detected in the sample (total peak area).

\subsection{Statistical Analysis}

All treatments were arranged in a completely randomized design. The data of percent inhibition of mycelial growth were transformed with the arcsine: $\sqrt{ }$ percent inhibition/100 [25]. Analysis of variance $(p \leq 0.05)$ and Tukey's test $(p \leq 0.05)$ were performed using the SAS statistical package (V. 9.0., SAS Inst. Inc., Cary, NC, USA).

\section{Results}

\subsection{Identification of Pathogenic Fungi of Blueberry and Pathogenicity Tests}

Three pathogens of blueberry were identified at the molecular level: Pestalotiopsis clavispora, Colletotrichum gloeosporioides and Lasiodiplodia pseudotheobromae. The three fungi inoculated into blueberry plants caused dark-colored lesions on the stems, loosening of the epidermis and brown coloration of the leaf-tips (cancers and dieback disease). 
The fungi were reisolated and identified from the lesions they caused to the plants, fulfilling Koch's postulates.

\subsection{Antifungal Effect In Vitro of Crude Extracts on the Mycelial Growth of Blueberry Pathogens}

The mycelial growth of blueberry pathogens was inhibited by at least one of the extracts from the plants under study. In the case of the treatments with L. hirta, the extract M5L (at a concentration of $5 \mathrm{mg} / \mathrm{mL}$ ) inhibited $100 \%$ of the growth of $P$. clavispora and C. gloeosporioides, the same results obtained with the positive controls (Figure 1(A1,A2,E1,E2), Table 1).

The inhibitory activity of this extract against $L$. pseudotheobromae was only $22 \%$, but it was significant $(p \leq 0.05)$ compared to the negative control (Figure 1(A3); Table 1). Other less effective extracts were $\mathrm{M} 8 \mathrm{Fl}$, which inhibited $24 \%$ of the growth of P. clavispora, and M1L, which inhibited $55 \%$ of the growth of $C$. gloeosporioides. A lower concentration of M5L $(2 \mathrm{mg} / \mathrm{mL}$ ) inhibited $21 \%$ of the growth of C. gloeosporioides (Table 1$)$.

In treatments with A. ochroleuca, the most effective extract was M6LFr (at a concentration of $5 \mathrm{mg} / \mathrm{mL}$ ), completely inhibiting the growth of P. clavispora and C. gloeosporioides, the same results obtained with positive controls containing Thiabendazole (Figure 1(B1,B2, E1,E2), Table 1). However, it had no effect on the mycelial growth of L. pseudotheobromae (Figure 1(B3); Table 1). Furthermore, the M3LFr extract showed significant inhibition $(p \leq 0.05)$ of $P$. clavispora $(59 \%)$ and C. gloeosporioides $(48 \%)$. The least effective extract was M9R (Table 1).

Regarding the treatments with A. porophyllum, the extract with the highest inhibitory activity was M4LS at a concentration of $5 \mathrm{mg} / \mathrm{mL}$, inhibiting $100 \%$ of the growth of the three phytopathogens, the same result obtained with positive controls (Figure 1(C1-C3,E1E3); Table 1). M4LS also showed significant inhibition $(p \leq 0.05)$ of L. pseudotheobromae at concentrations of 1 and $2 \mathrm{mg} / \mathrm{mL}$ (78.7 and 82.7\%, respectively). At a concentration of $5 \mathrm{mg} / \mathrm{mL}$, the M2LS extract inhibited $100 \%$ of C. gloeosporioides, whereas at $2 \mathrm{mg} / \mathrm{mL}$ it inhibited only $18 \%$, with significant differences compared to the negative control. The M7L extract $(5 \mathrm{mg} / \mathrm{mL})$ was not very effective against $P$. clavispora and $C$. gloeosporioides. None of the extracts (L. hirta, A. ochroleuca and A. porophyllum) was effective against the mycelium of blueberry fungi at doses of $0.5 \mathrm{mg} / \mathrm{mL}$ (Table 1 ).

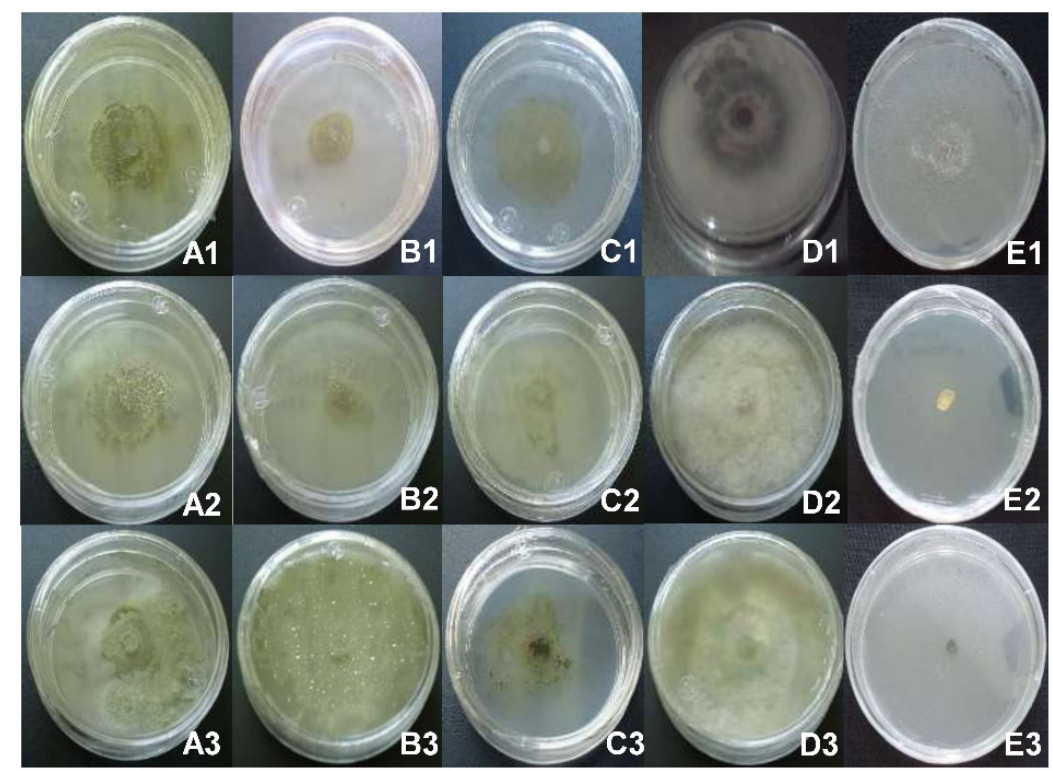

Figure 1. Inhibitory effect of the crude extracts: M5L of L. hirta (A), M6LFr of A. ochroleuca (B) and M4LS of A. porophyllum (C); on the mycelium of C. gloeosporioides (A1, B1 and C1), P. clavispora (A2, $\mathrm{B} 2$ and $\mathrm{C} 2$ ) and L. pseudotheobromae (A3, B3 and C3), at a concentration of $5 \mathrm{mg} / \mathrm{mL}$. The negative control was absolute ethanol (D), and the positive control Thiabendazole (E). 
Table 1. Percentage of mycelial growth inhibition of phytopathogenic fungi of blueberry by crude extracts of $L$. hirta, A. ochroleuca and A. porophyllum.

\begin{tabular}{|c|c|c|c|c|c|}
\hline \multirow{2}{*}{\multicolumn{2}{|c|}{ Extracts $^{\varepsilon}$}} & \multirow{2}{*}{$\begin{array}{c}\text { Concentration } \\
(\mathrm{mg} / \mathrm{mL})\end{array}$} & \multicolumn{3}{|c|}{ Inhibition (\%) } \\
\hline & & & P. clavispora & C. gloeosporioides & L. pseudotheobromae \\
\hline \multirow{2}{*}{\multicolumn{2}{|c|}{ M1L (EtOH) }} & $0.5,1,2$ & $0 \mathrm{~g}$ & $0^{\mathrm{j}}$ & $0^{\mathrm{e}}$ \\
\hline & & 5 & $5.4^{\mathrm{e}}$ & $55^{b}$ & $0^{\mathrm{e}}$ \\
\hline \multirow{2}{*}{\multicolumn{2}{|c|}{ M5L (AcOEt) }} & $0.5,1$ & $0 \mathrm{~g}$ & $0^{\mathrm{j}}$ & $0^{\mathrm{e}}$ \\
\hline & & 2 & $0^{g}$ & $21^{\mathrm{e}}$ & $0^{\mathrm{e}}$ \\
\hline \multirow[t]{7}{*}{ L. hirta } & & 5 & $100^{\mathrm{a}}$ & $100^{\mathrm{a}}$ & $22^{d}$ \\
\hline & M8Fl (AcOEt) & $0.5,1,2$ & $0^{g}$ & $0^{\mathrm{j}}$ & $0^{\mathrm{e}}$ \\
\hline & & 5 & $24^{c}$ & $30^{d}$ & $0^{\mathrm{e}}$ \\
\hline & M11Fl (EtOH) & $0.5,1,2,5$ & $0 \mathrm{~g}$ & $0^{j}$ & $0^{\mathrm{e}}$ \\
\hline & M3LFr (EtOH) & $0.5,1,2$ & $0 \mathrm{~g}$ & $0^{\mathrm{j}}$ & $0^{\mathrm{e}}$ \\
\hline & & 5 & $59^{b}$ & $48^{c}$ & $0^{\mathrm{e}}$ \\
\hline & M6LFr (AcOEt) & $0.5,1,2$ & $0^{g}$ & $0^{j}$ & $0^{\mathrm{e}}$ \\
\hline \multirow[t]{8}{*}{ A. ochroleuca } & & 5 & $100^{\mathrm{a}}$ & $100^{\mathrm{a}}$ & $0^{\mathrm{e}}$ \\
\hline & M9R (AcOEt) & $0.5,1,2$ & $0 \mathrm{~g}$ & $0^{j}$ & $0^{\mathrm{e}}$ \\
\hline & & 5 & $4^{\mathrm{f}}$ & $5^{\mathrm{i}}$ & $0^{\mathrm{e}}$ \\
\hline & M12R (EtOH) & $0.5,1,2,5$ & $0^{g}$ & $0^{j}$ & $0^{\mathrm{e}}$ \\
\hline & M2LS (EtOH) & $0.5,1$ & $0 \mathrm{~g}$ & $0^{j}$ & $0^{\mathrm{e}}$ \\
\hline & & 2 & $0^{g}$ & $18^{\mathrm{f}}$ & $0^{\mathrm{e}}$ \\
\hline & & 5 & $0^{g}$ & $100^{a}$ & $0^{\mathrm{e}}$ \\
\hline & M4LS (AcOEt) & 0.5 & $0 \mathrm{~g}$ & $0^{\mathrm{j}}$ & $0^{\mathrm{e}}$ \\
\hline \multirow[t]{6}{*}{ A. porophyllum } & & 1 & $0 \mathrm{~g}$ & $0^{\mathrm{j}}$ & $79^{c}$ \\
\hline & & 2 & $0^{g}$ & $13^{g}$ & $83^{b}$ \\
\hline & & 5 & $100^{a}$ & $100^{a}$ & $100^{a}$ \\
\hline & M7L (AcOEt) & $0.5,1,2$ & $0 \mathrm{~g}$ & $0^{\mathrm{j}}$ & $0^{\mathrm{e}}$ \\
\hline & & 5 & $7^{\mathrm{d}}$ & $10^{\mathrm{h}}$ & $0^{\mathrm{e}}$ \\
\hline & M10L (EtOH) & $0.5,1,2,5$ & $0^{g}$ & $0^{\mathrm{j}}$ & $0^{\mathrm{e}}$ \\
\hline \multicolumn{2}{|c|}{ Absolute control * } & - & $0 \mathrm{~g}$ & $0^{j}$ & $0^{\mathrm{e}}$ \\
\hline \multicolumn{2}{|c|}{ Negative control } & - & $0 \mathrm{~g}$ & $0^{j}$ & $0^{\mathrm{e}}$ \\
\hline \multicolumn{2}{|c|}{ Positive control } & 5 & $100^{a}$ & $100^{a}$ & $100^{a}$ \\
\hline
\end{tabular}

Different letters in the same column indicate significant differences $(p \leq 0.05) .{ }^{\varepsilon}$ M1-M12 = leaf extracts (L) and flower extracts (Fl) of L. hirta; leaf-fruit extracts (LFr) and root extracts (R) of A. ochroleuca; leaf-stem extracts (LS) and leaf extracts (L) of A. porophyllum. Absolute ethanol $(\mathrm{EtOH})$ and ethyl acetate (AcOEt) were used as solvents. ${ }^{*}$ Absolute control (PDA + fungus). Negative control (PDA + fungus + EtOH). Positive control (PDA + fungus + Thiabendazole, TECTO $\left.60^{\circledR}\right)$.

\subsection{Fractions of Crude Extracts and Identification of Bioactive Compounds}

The crude extracts that showed $100 \%$ antifungal activity in vitro were fractionated and evaluated. Nine of 10 fractions of the M5L extract of L. hirta showed significant antifungal activity $(p<0.05)$ compared to the negative control; the F10 fraction showed the highest percentages of inhibition (44.3\%) against $C$. gloeosporioides. Few fractions had effect against P. clavispora, as was the case of F6, with $11 \%$ inhibition (Table 2).

The secondary metabolites present in the F6 and F10 fractions of the M5L extract were Phytol (68.09\% abundance) for F6 and $\alpha$-sitosterol (44.80\% of abundance) for F10 (Figure 2). 
Table 2. Percentage of mycelial growth inhibition of P. clavispora and C. gloeosporioides by fractions from the M5L extract of L. hirta.

\begin{tabular}{cccc}
\hline \multirow{2}{*}{ Fractions } & $\begin{array}{c}\text { Concentration } \\
(\mathbf{m g} / \mathbf{m L})\end{array}$ & \multicolumn{2}{c}{ Inhibition (\%) } \\
\cline { 3 - 4 } & 1.8 & P. clavispora $^{\text {C. }}$ & gloeosporioides $^{\mathrm{e}}$ \\
F1 & 1.8 & $0^{\mathrm{e}}$ & $8.2^{\mathrm{g}}$ \\
F2 & 1.8 & $0^{\mathrm{e}}$ & $12.9^{\mathrm{e}}$ \\
F3 & 2.4 & $0^{\mathrm{e}}$ & $15.3^{\mathrm{d}}$ \\
F4 & $0^{\mathrm{e}}$ & $0^{\mathrm{j}}$ \\
F5 & 1.8 & $11.0^{\mathrm{b}}$ & $20.0^{\mathrm{c}}$ \\
F6 & 2.4 & $0^{\mathrm{e}}$ & $9.4^{\mathrm{f}}$ \\
F7 & $10.6^{\mathrm{c}}$ & $6.3^{\mathrm{h}}$ \\
F8 & 1.8 & $10.6^{\mathrm{c}}$ & $0^{\mathrm{j}}$ \\
F9 & 1.2 & $2.0^{\mathrm{d}}$ & $4.3^{\mathrm{i}}$ \\
F10 & 2.4 & $0^{\mathrm{e}}$ & $44.3^{\mathrm{b}}$ \\
Absolute control & 0.6 & $0^{\mathrm{e}}$ & $0^{\mathrm{j}}$ \\
Negative control & - & $100^{\mathrm{a}}$ & $0^{\mathrm{j}}$ \\
Positive control & - & $100^{\mathrm{a}}$ \\
\hline
\end{tabular}

Different letters in the same column indicate significant differences $(p \leq 0.05) .{ }^{*}$ Absolute control (PDA + fungus) Negative control (PDA + fungus + EtOH). Positive control (PDA + fungus + Thiabendazole, TECTO $\left.60^{\circledR}\right)$.

a)

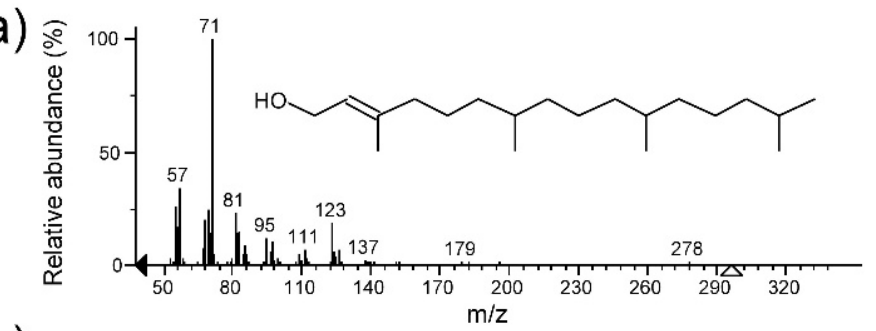

b)

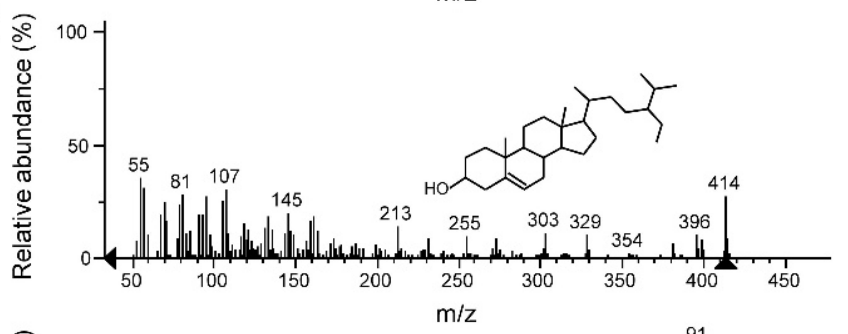

c)

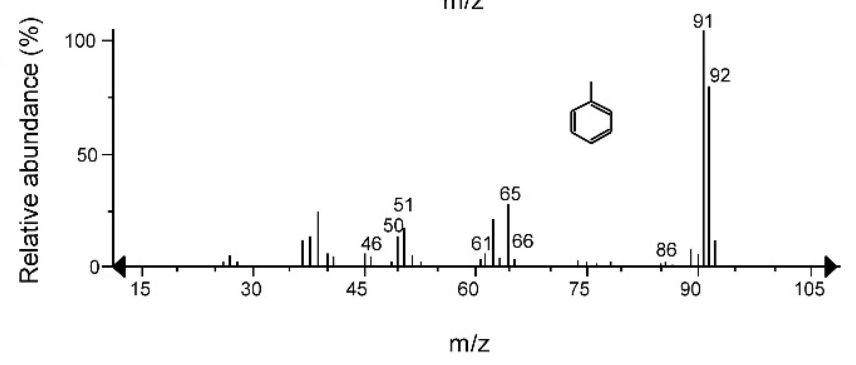

d)

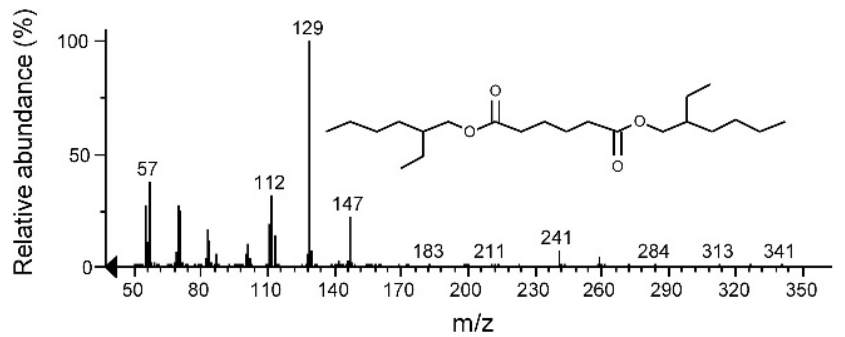

Figure 2. Mass spectra and chemical structures identified in the fractions F6 and F10 from the M5L extract of L. hirta, Phytol (a) and $\alpha$-sitosterol (b). In the fraction F10 from the M6LFr extract of A. ochroleuca, Toluene (c). In the fractions F2, F4 and F5 from the M4LS extract of A. porophyllum, Hexanedioic acid, bis(2-ethylhexyl) ester (d). 
The seventeen fractions from the M6LFr extract of A. ochroleuca showed significant antifungal activity $(p<0.05)$ against $P$. clavispora and $C$. gloeosporioides compared to the negative control. Fractions F13 (36\%) showed the highest inhibitory activity against P. clavispora, while F11 (26.0\%) had the highest inhibitory activity against $C$. gloeosporioides (Table 3). The secondary metabolites identified in fractions F13 and F11 from M6LFr extract were Toluene (53.7\% abundance) and Benzene, 1,3-bis(3-phenoxyphenoxy)- (100\% abundance), respectively (Figure 2).

Table 3. Percentage of mycelial growth inhibition of P. clavispora and C. gloeosporioides by fractions from the M6LFr extract of A. ochroleuca.

\begin{tabular}{cccc}
\hline \multirow{2}{*}{ Fractions } & $\begin{array}{c}\text { Concentration } \\
(\mathrm{mg} / \mathrm{mL})\end{array}$ & \multicolumn{2}{c}{ Inhibition (\%) } \\
\cline { 3 - 4 } & & P. clavispora & C. gloeosporioides \\
\hline F1 & 1.5 & $8.7^{\mathrm{j}}$ & $4.0^{\mathrm{n}}$ \\
F2 & 3.6 & $8.7^{\mathrm{j}}$ & $18^{\mathrm{g}}$ \\
F3 & 3 & $18.7^{\mathrm{i}}$ & $6.7^{\mathrm{m}}$ \\
F4 & 2.4 & $18.7^{\mathrm{i}}$ & $12.0^{\mathrm{j}}$ \\
F5 & 4.8 & $1.3^{1}$ & $8.0^{1}$ \\
F6 & 2.4 & $22.7^{\mathrm{g}}$ & $20.7^{\mathrm{e}}$ \\
F7 & 3 & $1.3^{1}$ & $24.0^{\mathrm{c}}$ \\
F8 & 1.8 & $28.0^{\mathrm{e}}$ & $20.0^{\mathrm{f}}$ \\
F9 & 1.2 & $28.0^{\mathrm{e}}$ & $21.3^{\mathrm{d}}$ \\
F10 & $34.7^{\mathrm{c}}$ & $20.0^{\mathrm{f}}$ \\
F11 & 0.6 & $27.3^{\mathrm{e}}$ & $26.0^{\mathrm{b}}$ \\
F12 & 1.8 & $34.7^{\mathrm{c}}$ & $18.0^{\mathrm{g}}$ \\
F13 & 1.2 & $36.0^{\mathrm{b}}$ & $16.0^{\mathrm{h}}$ \\
F14 & 3 & $24.0^{\mathrm{f}}$ & $22.0^{\mathrm{d}}$ \\
F15 & 1.2 & $20.7^{\mathrm{h}}$ & $13.3^{\mathrm{i}}$ \\
F16 & 1.2 & $4.0^{\mathrm{k}}$ & $10.0^{\mathrm{k}}$ \\
F17 & 1.2 & $33.3^{\mathrm{d}}$ & $20.0^{\mathrm{f}}$ \\
Absolute control & 1.2 & $0^{\mathrm{m}}$ & $0^{\mathrm{o}}$ \\
Negative control & - & $0^{\mathrm{m}}$ & $0^{\mathrm{o}}$ \\
Positive control & - & $100^{\mathrm{a}}$ & $100^{\mathrm{a}}$ \\
\hline
\end{tabular}

Different letters in the same column indicate significant differences $(p \leq 0.05) .{ }^{*}$ Absolute control (PDA + fungus) Negative control (PDA + fungus + EtOH). Positive control (PDA + fungus + Thiabendazole, TECTO $\left.60^{\circledR}\right)$.

The M4LS extract of A. porophyllum yielded eight fractions with significant antifungal activity $(p<0.05)$ against the three fungi under study. The fractions with the highest percentage of inhibition were F2 (34.9\%) against P. clavispora, F4 (12.2\%) against C. gloeosporioides and F5 (16.1\%) against L. pseudotheobromae (Table 4). Hexanedioic acid, bis (2-ethylhexyl) ester was identified in these three fractions, with percentages of abundance of $84.99 \%$, $91.34 \%$ and $100 \%$, respectively (Figure 2 ). 
Table 4. Percentage of mycelial growth inhibition of P. clavispora, C. gloeosporioides and L. pseudotheobromae by fractions from the M4LS crude extract of A. porophyllum.

\begin{tabular}{|c|c|c|c|c|}
\hline \multirow{2}{*}{ Fractions } & \multirow{2}{*}{$\begin{array}{l}\text { Concentration } \\
(\mathrm{mg} / \mathrm{mL})\end{array}$} & \multicolumn{3}{|c|}{ Inhibition (\%) } \\
\hline & & P. clavispora & C. gloeosporioides & L.pseudotheobromae \\
\hline F1 & 6.6 & $29.8^{c}$ & $7.8^{\mathrm{d}}$ & $4.7^{\mathrm{d}}$ \\
\hline $\mathrm{F} 2$ & 1.8 & $34.9^{b}$ & $6.7^{\mathrm{e}}$ & $14.1^{\mathrm{c}}$ \\
\hline F3 & 3 & $14.9^{\mathrm{e}}$ & $7.5^{\mathrm{d}}$ & $14.1^{\mathrm{c}}$ \\
\hline $\mathrm{F} 4$ & 3 & $26.3^{d}$ & $12.2^{b}$ & $1.6^{\mathrm{g}}$ \\
\hline F5 & 3 & $11.0^{\mathrm{f}}$ & $5.9^{f}$ & $16.1^{b}$ \\
\hline F6 & 1.2 & $6.7^{\mathrm{g}}$ & $7.5^{\mathrm{d}}$ & $3.1^{\mathrm{e}}$ \\
\hline F7 & 2.4 & $6.7^{\mathrm{g}}$ & $8.6^{\mathrm{e}}$ & $2.8^{\mathrm{f}}$ \\
\hline F8 & 4.2 & $5.9^{h}$ & $6.7^{\mathrm{e}}$ & $0^{h}$ \\
\hline Absolute control * & - & $0^{\mathrm{i}}$ & $0 \mathrm{~g}$ & $0^{\mathrm{h}}$ \\
\hline Negative control & - & $0^{\mathrm{i}}$ & $0^{g}$ & $0^{\mathrm{h}}$ \\
\hline Positive control & 5 & $100^{a}$ & $100^{a}$ & $100^{a}$ \\
\hline
\end{tabular}

Different letters in the same column indicate significant differences $(p \leq 0.05)$. ${ }^{*}$ Absolute control (PDA + fungus). Negative control (PDA + fungus + EtOH). Positive control (PDA + fungus + Thiabendazole, TECTO $\left.60^{\circledR}\right)$.

\section{Discussion}

The diseases affecting blueberry crops in northwestern Michoacán, Mexico, cause significant losses in production. This study identified three fungi that are often isolated from plants with symptoms of dieback and cancers: P. clavispora, C. gloeosporioides and L. pseudotheobromae. The first two have already been reported in blueberry crops by other studies [26,27], but we did not find reports of L. pseudotheobromae in blueberry, although it has been reported in other crops $[28,29]$.

Given the significant problems caused by these fungi in the cultivation of blueberry, the use of plant extracts from medicinal plants has been considered as a control alternative [30]. This study shows that extracts of L. hirta, A. ochroleuca and A. Porophyllum have antifungal activity in vitro. Among the best treatments, the inhibitory effect (100\%) of the extract M5L (AcOEt) of L. hirta on P. Clavispora and C. gloeosporioides was most prominent. Another study showed that extracts of other species of the same genus (L. camera) have an antifungal effect against $F$. oxysporum but not against $C$. gloeosporioides [8]. We found no reports on the antifungal effect of extracts of L. hirta against these or other pathogens of blueberry.

Another extract based on A. ochroleuca that inhibited 100\% of the growth of both pathogens (at a concentration of $5 \mathrm{mg} / \mathrm{mL}$ ) was M6LFr (AcOEt). These results are important because the antifungal effect of this extract was similar to that of the commercial fungicide Thiabendazole, which was used as positive control. Other studies have noted the antifungal effect of methanol extracts of A. ochroleuca against Fusarium sporotrichum ATCC 3299, Aspergillus niger, Trichophyton mentagrophytes and F. moniliforme [14].

The M4LS extract (AcOEt) of A. porophyllum was the only one that inhibited $100 \%$ of the three pathogenic fungi of blueberry, including L. pseudotheobromae, which was the most resistant fungus in this study. This is the first report of the antifungal effect of extracts of A. porophyllum against phytopathogenic fungi.

To carry out a preliminary approach to the chemical nature of the compounds present in fractions extracts with the highest antifungal activity, a GC-MS analysis was performed. The major compounds in the active fractions of the M5L extract of $L$. hirta were the diterpene Phytol and the triterpene $\alpha$-Sitosterol. Phytol is a common compound in extracts of plants such as Porophyllum linaria [31], Vitex negundo [32], Rhaponticum acaule [33] and Apium nodiflorum [34]. It has also been reported as one of the main components of the essential oil of $A$. nodiflorum, which showed antifungal activity against yeasts, dermatophytes, and Aspergillus spp. [34]. The triterpene $\alpha$-sitosterol has been isolated from Leucas aspera [35].

The compound identified in the most active fraction of the M6LFr extract of A. ochroleuca was Benzene, 1,3-bis (3-phenoxyphenoxy)-. The major compound in essential oil of Bridelia micrantha, Benzene, 1,3-bis (3-phenoxyphenoxy)- has shown antimicrobial activity against 
Mycobacterium tuberculosis [36]. However, there are no reports of this compound having antifungal activity against $P$. clavispora and $C$. gloeosporioides.

A single compound was identified in the three most active fractions from the M4LS extract of A. porophyllum: Hexanedioic acid, bis(2-ethylhexyl) ester. This compound has been isolated from the roots of Stellera chamaejasme [37], the stem of Hugonia mystax [38], and even from Streptomyces sp. [39]. This compound has shown antifungal activity against Monilinia fructicola [37] and Fusarium sp. [39]. However, it is necessary to carry out experiments that lead us to compounds purification and confirm their antifungal activity.

\section{Conclusions}

This study shows that extracts of the medicinal plants L. hirta, A. ochroleuca and A. porophyllum inhibited $100 \%$ of the mycelial growth in vitro of P. clavispora, C. gloeosporioides and L. pseudotheobromae at a concentration of $5 \mathrm{mg} / \mathrm{mL}$. Analysis by GC-MS indicates that the bioactive compounds present in the most effective extracts are the diterpene Phytol; the triterpenes $\alpha$-Sitosterol; and Toluene, Benzene, 1,3-bis(3-phenoxyphenoxy)- and Hexanedioic acid, bis(2-ethylhexyl) ester. This demonstrates the potential of L. hirta, A. ochroleuca and A. porophyllum as sources of antifungal compounds.

Author Contributions: Conceptualization, A.H.-C. and L.F.C.-T.; methodology, A.H.-C.; software, P.D.L.-L.; validation, Y.M.G.-R., G.F.G.-H. and J.R.M.-M.; formal analysis, F.J.E.-G.; investigation, A.H.-C.; resources, L.F.C.-T.; data curation, A.H.-C.; writing—original draft preparation, L.F.C.-T.; writing-review and editing, J.R.M.-M.; visualization, P.D.L.-L.; supervision, G.F.G.-H.; project administration, L.F.C.-T.; funding acquisition, P.D.L.-L. All authors have read and agreed to the published version of the manuscript.

Funding: This research received no external funding.

Institutional Review Board Statement: Not applicable.

Informed Consent Statement: Not applicable.

Data Availability Statement: The authors declare that the data supporting the findings of this study are available within the article.

Acknowledgments: The authors thank the Ignacio Garcia Ruiz (in charge of the herbarium CIMI of CIIDIR-IPN Unidad Michoacán) for identifying the medicinal plants, used in this study.

Conflicts of Interest: The authors declare no conflict of interest.

\section{References}

1. SIAP-SAGARPA. Servicio de Información Agroalimentaria y Pesquera-Secretaría de Agricultura, Ganadería, Desarrollo Rural, Pesca y Alimentación. Available online: https:/ / nube.siap.gob.mx/cierreagricola/ (accessed on 16 March 2021).

2. Bristow, P.; Ramsdell, D. Botrytis blight. In Compendium of Blueberry and Cranberry Diseases; Caruso, F., Ramsdell, D., Eds.; Amer Phytopathological Society: St. Paul, MN, USA, 1995; pp. 8-9.

3. Wharton, P.S.; Schilder, A.C. Novel infection strategies of Colletotrichum acutatum on ripe blueberry fruit. Plant Pathol. 2008, 57, 122-134. [CrossRef]

4. Espinoza, J.G.; Briceño, E.X.; Keith, L.M.; Latorre, B.A. Canker and twig dieback of blueberry caused by Pestalotiopsis spp. and a Truncatella sp. in Chile. Plant Dis. 2008, 92, 1407-1414. [CrossRef]

5. Sammonds, J.; Billones, R.; Rocchetti, M.; Ridgway, H.J.; Walter, M.; Jaspers, M.V. Survey of blueberry farms for Botryosphaeria dieback and crown rot pathogens. N. Z. Plant Prot. 2009, 62, 238-242. [CrossRef]

6. Kong, C.S.; Qiu, X.L.; Yi, K.S.; Yu, X.F.; Yu, L. First Report of Neofusicoccum vitifusiforme Causing Blueberry Blight of Blueberry in China. Plant Dis. 2010, 94, 1373. [CrossRef] [PubMed]

7. Díaz, P.; Cabrera, A.; Alem, D.; Larrañaga, P.; Ferreira, F.; Rizza, M.D. Antifungal activity of medicinal plant extracts against phytopathogenic fungus Alternaria spp. Chil. J. Agric. Res. 2011, 71, 231-239. [CrossRef]

8. Mdee, L.K.; Masoko, P.; Eloff, J.N. The activity of extracts of seven common invasive plant species on fungal phytopathogens. S. Afr. J. Bot. 2009, 75, 375-379. [CrossRef]

9. Salgado-Garciglia, R.; Molina-Torres, J.; López-Meza, J.E.; Loeza-Lara, P.D. Efecto del extracto crudo y los compuestos bioactivos de Heliopsis longipes sobre la incidencia de la antracnosis, micorrización y nodulación del frijol. Agrociencia 2008, 42, 679-687.

10. Ribera, A.E.; Zuñiga, G. Induced plant secondary metabolites for phytopatogenic fungi control: A review. J. Soil Sci. Plant Nutr. 2012, 12, 893-911. [CrossRef] 
11. Madariaga-Mazón, A.; Hernández-Alvarado, R.B.; Noriega-Colima, K.O.; Osnaya-Hernández, A.; Martinez-Mayorga, K. Toxicity of secondary metabolites. Phys. Sci. Rev. 2019, 4,1-11. [CrossRef]

12. Montes-Belmont, R.; Cruz-Cruz, V.; Martínez-Martínez, G.; Sandoval-García, G.; García-Licona, R.; Zilch-Domínguez, S.; BravoLuna, L.; Bermúdez-Torres, K.; Flores-Moctezuma, H.E.; Carvajal-Moreno, M. Propiedades antifúngicas en plantas superiores. Análisis retrospectivo de investigaciones. Rev. Mex. Fitopatol. 2000, 18, 125-131.

13. López-Villafranco, M.E.; Aguilar-Contreras, A.; Aguilar-Rodríguez, S.; Xolalpa-Molina, S. Las Verbenaceae empleadas como recurso herbolario en México: Una revisión etnobotánica-médica The Verbenaceae used as an herbal resource in Mexico: An ethnobotanical-medical review. Polibotánica 2017, 44, 195-216. [CrossRef]

14. Reyes, F.D.; Peña, C.J.; Canales, M.; Jiménez, M.; Meráz, S.; Hernandez, T. Antimicrobial activity of Argemone ochroleuca Sweet (Chicalote). Boletín Latinoam. Caribe Plantas Med. Aromáticas 2011, 10, 139-146.

15. Villareal, J.Á.; Villaseñor, J.L. Flora de Veracruz. Compositae. Tribu Tageteae; Sosa, V., Ed.; Instituto de Ecología, A.C.: Xalapa, Veracruz, México, 2005.

16. Agrios, G. Plant Pathology, 5th ed.; Elsevier Academic Press: Amsterdam, The Netherlands, 2005; ISBN 0080473784.

17. Raeder, U.; Broda, P. Rapid preparation of DNA from filamentous fungi. Lett. Appl. Microbiol. 1985, 1, 17-20. [CrossRef]

18. Barrera-Necha, L.L.; Bautista-Baños, S. Actividad Antifúngica de Polvos, Extractos y Fracciones de Cestrum nocturnum L. Sobre el Crecimiento Micelial de Rhizopus stolonifer (Ehrenb.:Fr.) Vuill. Rev. Mex. Fitopatol. 2008, 26, 27-31.

19. Castillo, F.; Hernández, D.; Gallegos, G.; Mendez, M.; Rodríguez, R.; Reyes, A.; Aguilar, C.N. In vitro antifungal activity of plant extracts obtained with alternative organic solvents against Rhizoctonia solani Kühn. Ind. Crops Prod. 2010, 32, 324-328. [CrossRef]

20. Barrera-Figueroa, B.E.; Loeza-Lara, P.D.; Hernández-García, A.; López-Mesa, J.E.; Molina-Torres, J.; del Río-Torres, R.E.N.; Martínez-Pacheco, M.M.; López-Gómez, R.; Salgado-Garciglia, R. Antibacterial activity of flower extracts from Helenium mexicanum H.B.K. Emir. J. Food Agric. 2011, 23, 258-264.

21. Waksmundzka-Hajnos, M.; Sherma, J.; Kowalska, T. Overview of the Field of TLC in Phytochemistry and the Structure of the Book. In Thin Layer Chromatography in Phytochemistry; Waksmundzka-Hajnos, M., Sherma, J., Kowalska, T., Eds.; CRC Press: Boca Raton, FL, USA, 2008; p. 874.

22. Sánchez-Pérez, J.D.L.; Jaimes-Lara, M.G.; Salgado-Garciglia, R.; López-Meza, J.E. Root extracts from Mexican avocado (Persea americana var. drymifolia) inhibit the mycelial growth of the oomycete Phytophthora cinnamomi. Eur. J. Plant Pathol. 2009, 124, 595-601. [CrossRef]

23. Pandey, D.K.; Tripathi, N.N.; Tripathi, R.D.; Dixit, S.N. Fungitoxic and phytotoxic properties of the essential oil of Hyptis suaveolens. J. Plant Dis. Prot. 1982, 89, 344-349.

24. Adams, R.P. Identification of Essential Oil Components by Gas Chromatography/Mass Spectrometry, 4th ed.; Allured Publishing Corporation: Carol Stream, IL, USA, 2007.

25. Ruiz-Sánchez, E.; Mejía-Bautista, M.A.; Cristóbal-Alejo, J.; Valencia-Botín, A.; Reyes-Ramírez, A. Actividad antagónica de filtrados de Bacillus subtilis contra Colletotrichum gloeosporioides (Penz.). Rev. Mex. Cienc. Agrícolas 2014, 5, 1325-1332. [CrossRef]

26. Mondragón, F.A.; López, M.J.; Ochoa, A.S.; Gutiérrez, C.M. Hongos Asociados a la Parte Aérea del Arándano en Los Reyes, Michoacán, México. Rev. Mex. Fitopatol. 2012, 30, 141-144.

27. Sabaratnam, S. Blueberry Anthracnose (Ripe Rot); British Columbia Ministry of Agriculture: Abbotsford, BC, Canada, 2018.

28. Tovar-Pedraza, J.M.; Mora-Aguilera, J.A.; Nava-Díaz, C.; Téliz-Ortiz, D.; Valdovinos-Ponce, G.; Villegas-Monter, Á.; HernándezMorales, J. Identification, pathogenicity, and histopathology of lasiodiplodia theobromae on mamey sapote grafts In Guerrero, México. Agrociencia 2012, 46, 147-161.

29. Sandoval-Sánchez, M.; Nieto-Ángel, D.; Sandoval-Islas, J.S.; Téliz-Ortiz, D.; Orozco-Santos, M.; Silva-Rojas, H.V. Hongos asociados a pudrición del pedúnculo y muerte descendente del mango (Mangifera Indica L.). Agrociencia 2013, 47, 61-73.

30. Kalidindi, N.; Thimmaiah, N.V.; Jagadeesh, N.V.; Nandeep, R.; Swetha, S.; Kalidindi, B. Antifungal and antioxidant activities of organic and aqueous extracts of Annona squamosa Linn. leaves. J. Food Drug Anal. 2015, 23, 795-802. [CrossRef]

31. Juárez, Z.N.; Hernández, L.R.; Bach, H.; Sánchez-Arreola, E.; Bach, H. Antifungal activity of essential oils extracted from Agastache mexicana ssp. xolocotziana and Porophyllum linaria against post-harvest pathogens. Ind. Crops Prod. 2015, 74, 178-182. [CrossRef]

32. Praveen Kumar, P.; Kumaravel, S.; Lalitha, C. Screening of antioxidant activity, total phenolics and GC-MS study of Vitex negundo. African J. Biochem. Res. 2010, 4, 191-195.

33. Boussaada, O.; Ammar, S.; Saidana, D.; Chriaa, J.; Chraif, I.; Daami, M.; Helal, A.N.; Mighri, Z. Chemical composition and antimicrobial activity of volatile components from capitula and aerial parts of Rhaponticum acaule DC growing wild in Tunisia. Microbiol. Res. 2008, 163, 87-95. [CrossRef] [PubMed]

34. Maxia, A.; Falconieri, D.; Piras, A.; Porcedda, S.; Marongiu, B.; Frau, M.A.; Gonçalves, M.J.; Cabral, C.; Cavaleiro, C.; Salgueiro, L. Chemical Composition and Antifungal Activity of Essential Oils and Supercritical CO 2 Extracts of Apium nodiflorum (L.) Lag. Mycopathologia 2012, 174, 61-67. [CrossRef] [PubMed]

35. Prajapati, M.; Patel, J.; Modi, K.; Shah, M. Leucas aspera: A review. Pharmacogn. Rev. 2010, 4, 85-87. [CrossRef]

36. Green, E.; Obi, L.C.; Samie, A.; Bessong, P.O.; Ndip, R.N. Characterization of n-Hexane sub-fraction of Bridelia micrantha (Berth) and its antimycobacterium activity. BMC Complement. Altern. Med. 2011, 11, 28. [CrossRef] [PubMed] 
37. Xue-Na, B.; Cheng, J.; Liang, W.; Lan-Qing, M.; Yu-Bo, L.; Guang-Lu, S.; You-Nian, W. Antifungal activity of extracts by supercritical carbon dioxide extraction from roots of Stellera chamaejasme L. and analysis of their constituents using GC-MS. In Advances in Intelligent and Soft Computing; Zhu, E., Sambath, S., Eds.; Springer: Berlin/Heidelberg, Germany, 2012; Volume 134, pp. 653-662, ISBN 9783642275364.

38. Vimalavady, A.; Kadavul, K. Phytocomponents identified on the various extracts of stem of Hugonia mystax L. (Linaceae). Pelagia Res. Libr. Eur. J. Exp. Biol. 2013, 3, 73-80.

39. Elleuch, L.; Shaaban, M.; Smaoui, S.; Mellouli, L.; Karray-Rebai, I.; Fourati-Ben Fguira, L.; Shaaban, K.A.; Laatsch, H. Bioactive secondary metabolites from a new terrestrial streptomyces sp. TN262. Appl. Biochem. Biotechnol. 2010, 162, 579-593. [CrossRef] [PubMed] 